\title{
Effects of mild zinc deficiency, plus or minus an acute-phase response, on galactosamine-induced hepatitis in rats
}

\author{
BY SUSAN E. PARSONS AND ROBERT A. DISILVESTRO* \\ Human Nutrition and Food Management, Ohio State University, 265 Campbell Hall, 1787 Neil \\ Avenue, Columbus, OH 43210, USA
}

(Received 19 April 1993 - Revised 7 January 1994 - Accepted 1 February 1994)

\begin{abstract}
Zn deficiency is hypothesized to produce poor resistance to injury involving oxidative stress. This could occur by impairing $\mathrm{Zn}$ antioxidant function(s) or by indirectly limiting adaptive protective mechanisms such as a rise in acute-phase proteins. The present study examined rats fed diets adequate or moderately low in $\mathrm{Zn}$ (4 or $25 \mu \mathrm{g} / \mathrm{g}$ diet) for $9 \mathrm{~d}$. The lower intake produced a mild $\mathrm{Zn}$ deficiency based on body weight, plasma $Z n$ and plasma alkaline phosphatase (EC 3.1.3.1) activity. Galactosamine injection, an oxidative stress, produced much more liver injury in the mildly Zn-deficient rats. However, injury was strongly inhibited in rats from each dietary group by an acute-phase response due to turpentine-induced leg inflammation. Mild $\mathrm{Zn}$ deficiency did not prevent a rise in levels of the acute-phase protein caeruloplasmin $(E C$ 1.16.3.1), but did limit the usual inflammation-induced rise in hepatic levels of metallothionein, a $\mathrm{Zn}$ protein with possible antioxidant function. In conclusion, high degrees of galactosamine-induced hepatitis were associated with mild $\mathrm{Zn}$ deficiency, but the liver injury was blocked by prior stimulation of an acute-phase response, regardless of $\mathrm{Zn}$ status.
\end{abstract}

Zinc: Galactosamine-induced hepatitis: Metallothionein

A recent review article (Bray \& Bettger, 1990) summarizes the evidence for and against the hypothesis that $\mathrm{Zn}$ performs antioxidant function(s). On the negative side, Zn-deficiency symptoms do not resemble those of the antioxidant nutrients Se or vitamin $\mathrm{E}$, nor do cell membranes from $\mathrm{Zn}$-deficient rodents show compositions expected after oxidative damage. On the other hand, $\mathrm{Zn}$ inhibits oxidative reactions in vitro, depresses radical production by activated isolated phagocytes, and stabilizes membranes against stress in vitro. Also, metallothionein, a protein which contains $\mathrm{Zn}$, can scavenge radicals in vitro. In addition, high-dose $\mathrm{Zn}$ injections in rats block injury due to $\mathrm{CCl}_{4}$ and radiation. One limitation of these studies supporting an antioxidant function for $\mathrm{Zn}$ is that the $\mathrm{Zn}$ levels and/or binding ligands produced are not necessarily typical of most physiological conditions.

Possibly, the main effects of impaired $\mathrm{Zn}$ antioxidant function(s) occur only during oxidative stress. A few studies have related dietary $\mathrm{Zn}$ deficiency with the potential for oxidative injury. For instance, lung microsomes from $\mathrm{Zn}$-deficient rats yield high quantities of carbon-centred radicals upon stimulation in vitro (Kubow et al. 1986). Also, liver microsomes from such rats show high lipid peroxidation induction in vitro (Sullivan et al. 1980). However, the relationship of these effects to oxidative injury in vivo is unclear.

Little research has actually examined the effects of varying dietary $\mathrm{Zn}$ on stress-induced injury in vivo. In one exception, Taylor et al. (1990) found that $\mathrm{Zn}$-deficient rats show excessive hyperoxia-induced lung damage. However, at least some of the effects may not

\footnotetext{
* For reprints.
} 
have involved impairment of specific $\mathrm{Zn}$ antioxidant functions. Instead, the high degree of injury may have resulted from an indirect effect on antioxidant enzyme levels due to a general impairment of protein synthesis. Hyperoxia injury develops over several days and can be influenced by the extent to which adaptive responses occur (Crapo et al. 1980). Taylor \& Bray (1991) found that Zn-deficient rats did not show the rise in antioxidant enzyme levels (i.e. superoxide dismutase, $E C$ 1.15.1.1) normally seen during hyperoxia.

The present study tested the hypothesis that $\mathrm{Zn}$ deficiency could affect resistance to an oxidative stress through mechanisms other than general restriction of protein synthesis. One way in which this was accomplished was by using galactosamine injection as the oxidative stress. This treatment injures the liver quickly while blocking hepatic protein synthesis (Decker \& Keppler, 1974). Thus, impaired liver synthesis of serum acute-phase proteins or antioxidant enzymes within the liver should not have been dependent on $\mathrm{Zn}$ status. In effect, all galactosamine-treated rats, regardless of dietary treatment, would have an impairment. Furthermore, the study used a mild $\mathrm{Zn}$ deficiency which should not have a major impact on protein synthesis. This assumption about mild $\mathrm{Zn}$ deficiency was tested by examining its effects on the protection against galactosamine normally afforded by first elevating the synthesis of acute-phase proteins (Alcorn et al. 1992). In the present study this elevation was accomplished by pretreatment with leg inflammation induced by intramuscular turpentine injection.

Galactosamine is considered to be an oxidative stress resembling that of viral hepatitis (Shedlofsky \& McClain, 1991). In both cases, liver injury is thought to occur because these agents increase the sensitivity of this organ to the low levels of endotoxin generally present in mammals (Chojkier \& Fierer, 1985; Shedlofsky \& McClain, 1991). Evidence for $O$ radical involvement includes observations that galactosamine-induced injury is limited by injection with antioxidants such as superoxide dismutase, allopurinol or catalase (EC 1.11.1.6; Shedlofsky \& McClain, 1991).

\section{MATERIALS AND METHODS}

Animal diets and treatments

The animal protocol was approved by The Ohio State University Institutional Laboratory Animal Care Committee. Male Sprague-Dawley rats, initially weighing about $150 \mathrm{~g}$, were obtained from Harlan Sprague-Dawley (Indianapolis, IN, USA) and housed singly in stainless steel cages. Rats were given deionized water and a semipurified diet obtained from ICN Biochemicals (Cleveland, OH, USA) shown in Table 1. The low- and adequate- $\mathrm{Zn}$ diets contained 4 and $25 \mathrm{mg} \mathrm{Zn} / \mathrm{kg}$ respectively, measured by atomic absorption spectrometry. For the first $5 \mathrm{~d}$ after arrival all rats were given the adequate- $\mathrm{Zn}$ diet $a d$ lib. Rats were then either continued on the same dietary regimen, switched to the low- $\mathrm{Zn}$ diet or given the adequate-Zn diet pair-fed to the average intake for rats consuming the low$\mathrm{Zn}$ diet. Rats used for injury evaluations were killed $9 \mathrm{~d}$ later. Rats used to measure caeruloplasmin and metallothionein were killed a day earlier. All rats were killed by decapitation after a brief exposure to $\mathrm{CO}_{2}$. When an acute-phase response was produced, inflammation was initiated with turpentine $(0 \cdot 1 \mathrm{ml} / \mathrm{rat}$, given intra-muscularly in the leg) $2 \mathrm{~d}$ before the rats were killed. Leg swelling was visible the day after turpentine injection. Galactosamine (Sigma Chemical Co., St Louis, MO, USA), when injected, was given intraperitoneally at $1 \mathrm{~g} / \mathrm{kg}$ body weight in saline $(9 \mathrm{~g} \mathrm{NaCl} / 1) 1 \mathrm{~d}$ before the rats were killed. Most serum measurements used to assess galactosamine-induced liver injury reach peak or near peak values in young rats about $1 \mathrm{~d}$ after injection (Platt et al. 1978; Tsuda et al. 1990; Farghali et al. 1991). 
Table 1. Composition of the experimental diet $(\mathrm{g} / \mathrm{kg})$

\begin{tabular}{lc}
\hline \hline & $180 \cdot 0$ \\
Egg white & $100 \cdot 0$ \\
Maize oil & $443 \cdot 0$ \\
Maize starch & $200 \cdot 0$ \\
Sucrose & $30 \cdot 0$ \\
Alphacel hydrolyzed & $2 \cdot 0$ \\
Choline bitartrate & $0 \cdot 02$ \\
Biotin & $10 \cdot 0$ \\
AIN-76C vitamin mixture & $35 \cdot 0$ \\
\hline AIN-76 mineral mixture*
\end{tabular}

For the low-Zn diet, $\mathrm{ZnCO}_{3}$ was omitted.

\section{Analytical methods}

Serum $\mathrm{Zn}$ was measured by atomic absorption spectrometry. Serum bile acids and activities of alanine aminotransferase (ALT; $E C$ 2.6.1.2), $\beta$-glucuronidase (EC 3.2.1.31) and alkaline phosphatase $(E C 3.1 .3 .1)$ were measured spectrophotometrically using kits from Sigma Chemical Co. ALT was measured by first catalysing the conversion of alanine plus 2-oxoglutarate to glutamate plus pyruvate. The latter acts as a substrate for lactate dehydrogenase (EC 1.1.1.27) which converts NADH to NAD, a process followed by a decrease in absorbance at $340 \mathrm{~nm}$. $\beta$-glucuronidase was assessed by liberation of the dye phenolphthalein from phenophthalein mono- $\beta$-glucuronic acid. Alkaline phosphatase was detected by cleavage of phosphate from $p$-nitrophenyl phosphate at alkaline $\mathrm{pH}$, forming the yellow compound $p$-nitrophenol. The bile assay used $3 \alpha$-hydroxysteroid dehydrogenase ( $E C$ 1.1.1.50) to convert the bile acids to 3-oxo bile acids with the concurrent generation of NADH. The latter, through the action of diaphorase $(E C 1.8 .1 .4)$, reacts with the dye nitro blue tetrazolium. Serum sialic acid levels were assayed with a kit from Boehringer Mannheim (Indianapolis, IN, USA) which uses a series of enzyme steps to cleave sialic acid from proteins and ultimately produces a red chromophore. Caeruloplasmin $E C$ 1.16.3.1) activities were evaluated by oxidation of $p$-phenylenediamine by the method of Rice (1962). Metallothionein levels were assessed by the ${ }^{109} \mathrm{Cd}$-haemoglobin method (Eaton \& Toal, 1982). Serum was stored for less than $2 \mathrm{~d}$ at $4^{\circ}$ for caeruloplasmin, $\mathrm{Zn}$ and ALT determinations and at $-80^{\circ}$ for other analyses. Livers were stored at $-20^{\circ}$ before metallothionein assay. All results were analysed by ANOVA plus least significant differences (LSD; Steel \& Torrie, 1980) with $P<0.05$ considered significant.

\section{RESULTS}

Consumption of the moderately-low- $\mathrm{Zn}$ diet affected body-weight, serum $\mathrm{Zn}$ and serum alkaline phosphatase activity (Table 2). The degree of deficiency produced could be termed mild based on the values of Table 2 compared with those found for other studies of low $\mathrm{Zn}$ intake by rats (i.e. Luecke et al. 1968; Kubow et al. 1986; Taylor et al. 1990). For instance, the $\mathrm{Zn}$-adequate rats in the study of Kubow et al. $(1986)$ showed a mean plasma $\mathrm{Zn}$ value similar to that for adequate $\mathrm{Zn}$ in Table 2. In contrast, the mean value for the low- $\mathrm{Zn}$ group in the study of Kubow et al. (1986) was only about $40 \%$ of that in Table 2 for the rats given low $\mathrm{Zn}$. The classification of mild $\mathrm{Zn}$ deficiency for the present study is also supported by the observation that rats given moderately low $\mathrm{Zn}$ showed normal liver metallothionein levels (Table 2). Levels are below normal in more severely $\mathrm{Zn}$-deficient rats (Blalock et al. 1988). Pair-fed rats of Table 2 showed below normal body-weight gain, but not as low as seen during pair-feeding to more severely $\mathrm{Zn}$-deficient rats (i.e. Luecke et al. 1968; Kubow 
Table 2. Effects of dietary treatment on Zn status assessors in rats: body weight $(\mathrm{g})$, serum $\mathrm{Zn}($ umol/l), alkaline phosphatase $(A P, \mathrm{EC} \mathrm{3.1.3.1;} \mathrm{units/l)} \mathrm{and} \mathrm{liver} \mathrm{metallothionein}$ $(\mathrm{nmol} / \mathrm{g})^{*}$

(Mean values with their standard errors for five to seven rats)

\begin{tabular}{|c|c|c|c|c|c|c|c|c|}
\hline \multirow[b]{2}{*}{ Diet group } & \multicolumn{2}{|c|}{ Body wt } & \multicolumn{2}{|c|}{ Serum $\mathrm{Zn}$} & \multicolumn{2}{|c|}{$\mathbf{A P} \dagger$} & \multicolumn{2}{|c|}{ Metallothionein } \\
\hline & Mean & SE & Mean & SE & Mean & SE & Mean & $\mathrm{SE}$ \\
\hline Zn-adequate & $242^{e}$ & 13 & $2 \cdot 6^{b}$ & $0 \cdot 2$ & $340^{b}$ & 20 & $1.9^{\mathrm{a}}$ & 0.3 \\
\hline Pair-fed & $217^{\mathrm{b}}$ & 7 & $2 \cdot 6^{\mathrm{b}}$ & 0.2 & $280^{\mathrm{b}}$ & 40 & $1 \cdot 7^{\mathrm{a}}$ & 0.5 \\
\hline Low-Zn & $187^{\mathrm{a}}$ & 5 & $1 \cdot 8^{a}$ & $0 \cdot 1$ & $160^{\mathrm{a}}$ & 30 & $1 \cdot 7^{\mathrm{a}}$ & 0.3 \\
\hline
\end{tabular}

$\mathbf{a}, \mathbf{b}, \mathbf{0}$ Mean values within a column bearing different superscript letters were significantly different $(P<0 \cdot 01)$ by one-way ANOVA and least square differences.

* For details of diets and procedures, see Table 1 and pp. 612-613.

$\uparrow \mathrm{AP}$ activity is given in Sigma units ( 1 unit is sufficient to liberate $1 \mu \mathrm{mol} p$-nitrophenol/h from $p$-nitrophenyl phosphate at alkaline $\mathrm{pH}$ ).

et al. 1986; Taylor et al. 1990). Pair-feeding did not affect serum $\mathrm{Zn}$ nor alkaline phosphatase values (Table 2).

In all dietary groups, galactosamine injection produced a significant increase in serum ALT activities (Fig. 1), a measure of cell membrane damage (Korsrud et al. 1972). However, the mean increase was higher with mild Zn deficiency than for either group given adequate $\mathrm{Zn}$. Both adequate- $\mathrm{Zn}$ groups showed the same amount of galactosamineinduced injury. For this reason, as well as the small difference in feed intake and body weight between the pair-fed and ad libitum adequate-Zn groups, a pair-fed group was omitted from the remainder of the study.

A new set of rats was fed on either moderately-low or adequate- $\mathrm{Zn}$ diets as done for Table 2 and Fig. 1, only without the pair-fed group. One purpose was to confirm the strong, though variable, effects of low $\mathrm{Zn}$ intake on injury due to galactosamine. In addition, this experiment evaluated whether $\mathbf{Z n}$ status would affect the protection against galactosamine normally produced by an acute-phase response (Alcorn $e t$ al. 1992). As found previously (Table 2), rats fed low-Zn diets showed mild $\mathrm{Zn}$ deficiency based on moderately low serum Zn (data not shown) and normal liver metallothionein values (Table 3). Galactosamine again produced a high degree of injury in the mildly $\mathrm{Zn-deficient} \mathrm{rats} \mathrm{(Table}$ 4). However, the protective effect of an acute-phase response, brought on by leg inflammation, overcame this tendency toward a high degree of injury. Elevated serum levels of caeruloplasmin, an acute-phase protein (Cousins, 1985), demonstrated that an increase in acute-phase protein levels could occur in the mildly $\mathrm{Zn}$-deficient rats (Table 3). Caeruloplasmin was measured by activity, not protein, but the two variables are generally increased to the same extent by inflammation in rats (DiSilvestro et al. 1988). Serum sialic acid, a crude measure of acute-phase protein levels (Blatteis, 1985), was also increased with inflammation in both dietary Zn groups (data not shown). In contrast, the deficient rats, unlike those fed on the $\mathrm{Zn}$-adequate diet, did not show increased hepatic levels of the $\mathrm{Zn}$ containing protein metallothionein (Table 3).

Table 5 shows that two assessors of liver injury other than ALT activities showed the same patterns seen for ALT in Table 4. High $\beta$-glucuronidase values reflect hepatocellular necrosis (Ohta et al. 1992). High serum bile concentrations indicate liver functional impairment where bile leaks into the blood faster than it can be passed down the biliary system (Tsuda et al. 1990). Poor uptake of bile acids from portal blood may also occur. 


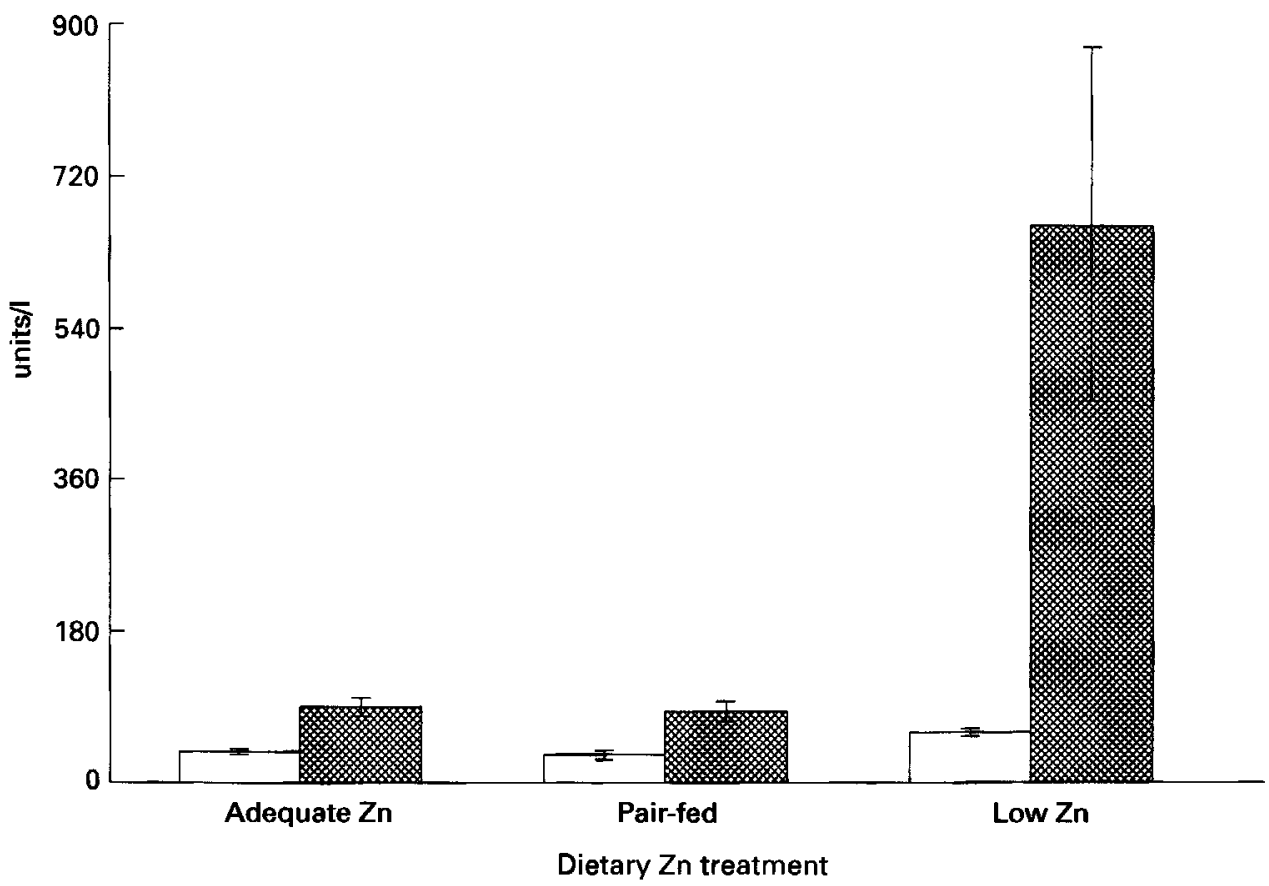

Fig. 1. Effects of $\mathrm{Zn}$ status and galactosamine injection on serum alanine aminotransferase (EC 2.6.1.2) activities in the rat. Values are means with their standard errors represented by vertical bars for five rats per control group ( $\square$ ) and six to nine rats for galactosamine-treated groups (B). One unit of activity was that required to produce $1 \mu \mathrm{mol} \mathrm{NAD} / \mathrm{min}$ from NADH under standard conditions. Values for all galactosamine-treated groups were significantly different from untreated controls, and the treated, low-Zn group was significantly different from the other treated groups $(P<0 \cdot 01$, two-way ANOVA and least significant differences).

Table 3. Effects of Zn intake plus or minus acute-phase response on liver metallothionein $(\mathrm{nmol} / \mathrm{g})$ and serum caeruloplasmin (EC 1.16.3.1; units $/ \mathrm{l})$ in rats*

(Mean values with their standard errors for five rats)

\begin{tabular}{|c|c|c|c|c|}
\hline \multirow[b]{2}{*}{ Treatment } & \multicolumn{2}{|c|}{ Metallothionein } & \multicolumn{2}{|c|}{ Caeruloplasmin $\uparrow$} \\
\hline & Mean & SE & Mean & $\mathrm{SE}$ \\
\hline $\begin{array}{l}\text { Adequate } \mathrm{Zn} \\
+ \text { inflammation } \neq\end{array}$ & $\begin{array}{l}1 \cdot 5^{a} \\
5 \cdot 6^{b}\end{array}$ & $\begin{array}{l}0.1 \\
0.8\end{array}$ & $\begin{array}{r}800^{a} \\
2080^{c}\end{array}$ & $\begin{array}{r}90 \\
100\end{array}$ \\
\hline $\begin{array}{l}\text { Low } \mathrm{Zn} \\
\quad+\text { inflammation } \neq\end{array}$ & $\begin{array}{l}1 \cdot 3^{\mathrm{a}} \\
1 \cdot 3^{\mathrm{a}}\end{array}$ & $\begin{array}{l}0 \cdot 2 \\
0 \cdot 3\end{array}$ & $\begin{array}{l}1280^{b} \\
3520^{d}\end{array}$ & $\begin{array}{l}120 \\
650\end{array}$ \\
\hline
\end{tabular}

a,b,c,d Mean values within a column bearing different superscript letters were significantly different $(P<0.01)$ by one-way ANOVA and least significant differences.

* For details of diets and procedures, see Table 1 and pp. 612-613.

$\dagger$ Caeruloplasmin units were arbitrarily defined as the change in absorbance at $540 \mathrm{~nm}$ over a 15 -min period.

t. An acute-phase response was produced by turpentine-induced inflammation of the leg. For details see p. 612 .

A fairly high degree of variation occurred for the assessors of injury, but this is typical for studies of galactosamine-induced injury (Platt et al. 1978). The assays themselves show low variation as evidenced by between-day coefficient of variation values of $3 \%$ (ALT), $2 \%$ ( $\beta$-glucuronidase) and $3.5 \%$ (bile acids). 
Table 4. Effects of $\mathrm{Zn}$ intake plus or minus an acute-phase response on serum alanine aminotransferase (EC 2.6.1.2)* activities (units/l) in the rat $\dagger$

(Mean values with their standard errors for six to nine rats)

\begin{tabular}{|c|c|c|c|c|}
\hline & \multicolumn{4}{|c|}{ Dietary group } \\
\hline & \multicolumn{2}{|c|}{ Adequate $\mathrm{Zn}$} & \multicolumn{2}{|c|}{ Low $\mathrm{Zn}$} \\
\hline & Mean & SE & Mean & SE \\
\hline Control & $43^{\mathrm{ab}}$ & 5 & $65^{\mathrm{c}}$ & 6 \\
\hline Inflammation $\ddagger$ & $32^{\mathrm{a}}$ & 5 & $35^{\mathrm{a}}$ & 6 \\
\hline Galactosamine & $98^{d}$ & 23 & $491^{\mathrm{e}}$ & 103 \\
\hline Inflammation $\ddagger+$ galactosamine & $40^{\mathrm{a}}$ & 5 & $55^{\mathrm{bc}}$ & 7 \\
\hline
\end{tabular}

a, b,c, d, e Mean values bearing different superscripts were significantly different $(P<0.01)$ by two-way ANOVA and least significant differences.

* One unit of activity is that required to produce $1 \mu \mathrm{mol} \mathrm{NAD} / \mathrm{min}$ from NADH under standard conditions.

$\dagger$ For details of diets and procedures, see Table 1 and pp. 612-613.

$\ddagger$ An acute-phase response was produced by turpentine-induced inflammation of the leg. For details see p. 612 .

Table 5. Effects of $\mathrm{Zn}$ intake plus and minus an acute-phase response on serum $\beta$-glucuronidase (EC 3.2.1.31) activities (units $\times 10^{-3} / l$ ) and bile acid concentrations $(\mu \mathrm{mol} / \mathrm{l})$ in the rat*

(Mean values with their standard errors for six to nine rats)

\begin{tabular}{|c|c|c|c|c|}
\hline \multirow[b]{2}{*}{ Treatment } & \multicolumn{2}{|c|}{ Bile acids } & \multicolumn{2}{|c|}{ Glucuronidase $\dagger$} \\
\hline & Mean & SE & Mean & $\mathrm{SE}$ \\
\hline Adequate $\mathrm{Zn}$ & $30^{\mathrm{a}}$ & 6 & $102^{\mathrm{a}}$ & 4 \\
\hline + Inflammation & $22^{\mathrm{a}}$ & 7 & $90^{\mathrm{a}}$ & 4 \\
\hline + Galactosamine & $58^{\mathrm{b}}$ & 6 & $195^{\mathrm{c}}$ & 14 \\
\hline + Inflammation $\ddagger$, galactosamine & $40^{a}$ & 3 & $135^{\mathrm{b}}$ & 11 \\
\hline Low $\mathrm{Zn}$ & $12^{\mathrm{a}}$ & 5 & $93^{\mathrm{a}}$ & 10 \\
\hline + Inflammation $\$$ & $9^{\mathrm{a}}$ & 5 & $82^{\mathrm{a}}$ & 6 \\
\hline + Galactosamine & $115^{\mathrm{c}}$ & 25 & $279^{\mathrm{d}}$ & 41 \\
\hline + Inflammation $\ddagger$, galactosamine & $21^{a}$ & 6 & $138^{\mathrm{b}}$ & 10 \\
\hline
\end{tabular}

a, b, c, d Mean values within a column bearing different superscript letters were significantly different $(P<0 \cdot 05)$ by two-way ANOVA and least significant differences.

* For details of diets and procedures, see Table 1 and pp. 612-613.

$\dagger \beta$-glucuronidase activity was measured in modified Sigma units (1 unit is sufficient for the formation of $1 \mu \mathrm{g}$ phenolphalein/h from phenolphthalein mono- $\beta$-glucuronic acid under standard conditions).

$\ddagger$ An acute-phase response was produced by turpentine-induced inflammation of the leg. For details see p. 612 .

\section{DISCUSSION}

This study demonstrated that a mild $\mathrm{Zn}$ deficiency can produce poor resistance to injury from a type of oxidative stress. It is not yet known whether this effect resulted from impairment in some direct antioxidant function of $\mathrm{Zn}$, or from some other alteration in the pathological process. However, the effect was not dependent on impaired ability to accumulate acute-phase proteins. The galactosamine treatment already restricts such accumulation (Decker \& Keppler, 1974; Alcorn et al. 1992). Also, the capability to increase levels of an acute-phase protein, caeruloplasmin, was present in the mildly deficient rats 
(Table 3). An increase in caeruloplasmin due to hyperoxia is inhibited in more severely $\mathrm{Zn}$ deficient rats (Taylor \& Bray, 1991).

The $\mathrm{Zn}$-binding protein metallothionein has been proposed to protect against $\mathrm{O}$ radicalmediated injury (Sato \& Bremner, 1993). However, variations in liver metallothionein levels did not contribute to the injury outcomes measured in this study. The high degree of galactosamine-induced liver injury in the mildly Zn-deficient rats occurred despite normal metallothionein values (Table 2, Fig. 1). Furthermore, inflammation pretreatment protected against liver injury in the $\mathrm{Zn}$-deficient rats despite low $\mathrm{Zn}$ intake abolishing the rise in liver metallothionien concentrations (Tables 3 and 4). These results do not support an antioxidant role for metallothionein. However, this role is supported by work from our laboratory which examines another hepatoxin, $\mathrm{CCl}_{4}$ (DiSilvestro \& Carlson, 1993). In that case, the protection normally afforded by leg inflammation was partially lost when elevations in metallothionein levels were blocked by mild $\mathrm{Zn}$ deficiency.

In conclusion, the present study demonstrates that mild $\mathrm{Zn}$ deficiency can affect susceptibility to an injury thought to involve the actions of $O$ free radicals. The mechanisms responsible for the $\mathrm{Zn}$ effects seen in this study await clarification. Possible mechanisms include membrane destabilization and exaggerated free radical production, both proposed consequences of impaired $\mathrm{Zn}$ function (Bray \& Bettger, 1990).

This work was supported by a grant from the National Livestock and Meat Board. The authors thank Elizabeth Joseph and Kathleen Trela for fine technical assistance.

\section{REFERENCES}

Alcorn, J. M., Fierer, J. \& Chojkier, M. (1992). The acute-phase response protects mice from D-galactosamine sensitization to endotoxin and tumor necrosis factor- $\alpha$. Hepatology 15, 122-129.

Blalock, L. T., Dunn, M. A. \& Cousins, R. J. (1988). Metallothionein gene expression in rats: tissue specific regulation by dietary copper and zinc. Journal of Nutrition 118, 222-228.

Blatteis, C. M. (1985). Central nervous system effects of interleukin-1. In The Physialogical, Metabolic, and Immunological Actions of Interleukin-1, pp. 107-120 [M. J. Kluger, J. J. Oppenheim and M. C. Powanda, editors]. New York: Alan R. Liss, Inc.

Bray, T. M. \& Bettger, W. J. (1990). The physiological role of zine as an antioxidant. Free Radical Biology and Medicine 8, 281-291.

Chojkier, M. \& Fierer, J. (1985). D-Galactosamine hepatotoxicity is associated with endotoxin sensitivity and mediated by lymphoreticular cells in mice. Gastroenterology 88, 115-121.

Cousins, R. J. (1985). Absorption, transport, and hepatic metabolism of copper and zinc: special reference to metallothionein and ceruloplasmin. Physiological Reviews 65, 238-309.

Crapo, J. D., Barry, B. E., Foscue, H. A. \& Shelburne, J. (1980). Structural and biochemical changes in rat lungs occurring during exposures to lethal and adaptive doses of oxygen. American Review of Respiratory Diseases 122, 123-143.

Decker, K. \& Keppler, D. (1974). Galactosamine hepatitis: key role of the nucleotide deficiency period in the pathogenesis of cell injury and cell death. Reviews of Physiology, Biochemistry and Pharmacology 71, 78-102.

DiSilvestro, R. A., Barber, E. F., David, E. A. \& Cousins, R. J. (1988). An enzyme linked immunoadsorbent assay for rat ceruloplasmin. Biological Trace Element Research 17, 1-9.

DiSilvestro, R. A. \& Carlson, G. P. (1994). Effects of mild zinc deficiency, plus or minus acute phase response, on $\mathrm{CCl}_{4}$ hepatotoxicity. Free Radical Biology \& Medicine 16, 57-61.

Eaton, D. L. \& Toal, B. F. (1982). Evaluation of the Cd/hemoglobin affinity assay for the rapid determination of metallothionein in biological tissues. Toxicology and Applied Pharmacology 66, 134-142.

Farghali, H., Gasbarrini, A., Borle, A. B., Nalesnik, M. A., Francavilla, A., Fagiuoli, S., Starzi, T. E. \& Van Thiel, D. H. (1991). FK 506 modulates D-galactosamine-induced hepatitis in rats. Transplantation Proceedings 23, 2809-2811.

Korsrud, G. O., Grice, H. C. \& McLaughlan, J. M. (1972). Sensitivity of several serum enzymes in detecting carbon tetrachloride-induced liver damage in rats. Toxicology and Applied Pharmacology 22, 474483.

Kubow, S., Bray, T. M. \& Bettger, W. J. (1986). Effects of dietary zinc and copper on free radical production in rat lung and liver. Canadian Journal of Physiology and Pharmacology 64, 1281-1285.

Luecke, R. W., Olman, M. E. \& Baltzer, B. U. (1968). Zinc deficiency in the rat: effect on serum and intestinal alkaline phosphatase activities. Journal of Nutrition 94, 344-350. 
Ohta, H., Ono, M., Sekiya, C. \& Namiki, N. (1992). Serum immunoreactive $\beta$-glucuronidase determined by an enzyme-linked immunosorbent assay in patients with hepatic diseases. Clinica Chimica Acta 208, 9-21.

Platt, D., Forster, K. \& Forster, L. (1978). Age dependent kinetic studies of cytoplasmic and lysosomal enzymes of the normal and D-galactosamine injured rat liver. Mechanisms of Ageing and Development 7, 183-188.

Rice, E. W. (1962). Standardization of ceruloplasmin activity in terms of international enzyme units. Analytical Biochemistry 3, 452-456.

Sato, M. \& Bremner, I. (1993). Oxygen free radicals and metallothionein. Free Radical Biology and Medicine 14, 325-327.

Shedlofsky, S. I. \& McClain, C. J. (1991). Hepatic dysfunction due to cytokines. In Cytokines and Inflammation, pp. 235-273 [E. S. Kimbal, editor]. Boca Ration: CRC Press.

Steel, R. D. G. \& Torrie, J. H. (1980). Principles and Procedures of Statistics, A Biometrical Approach, 2 nd ed. New York: McGraw-Hill.

Sullivan, J. F., Jetton, M. M., Hahn, H. K. J. \& Burch, R. E. (1980). Enhanced lipid peroxidation in liver microsomes of zinc-deficient rats. American Journal of Clinical Nutrition 33, 51-56.

Taylor, C. G. \& Bray, T. M. (1991). Effect of hyperoxia on oxygen free radical defense enzymes in the lung of zincdeficient rats. Journal of Nutrition 121, 460-466.

Taylor, C. G., Towner, R. A., Janzen, E. G. \& Bray, T. M. (1990). MRI detection of hyperoxia-induced lung edema in Zn-deficient rats. Free Radical Biology and Medicine 9, 229-233.

Tsuda, H., Wada, S., Masui, T., Inui, M., Ito, N., Katagiri, K., Hoshino, M., Inaguma, H., Miyagi, M. \& Takeuchi, T. (1990). Comparative sequential changes in serum and biliary levels of bile acid components after a single dose of $\mathrm{D}$-galactosamine or partial hepatectomy in the rat. Liver 10, 28-34. 